\title{
A CARBON FOOTPRINT FROM WOOD PELLET
}

\author{
UDC 502:622.788:620.91
}

\author{
Milica Jović ${ }^{1}$, Mirjana Laković ${ }^{1}$, Marjan Jovčevski ${ }^{2}$ \\ ${ }^{1}$ Faculty of Mechanical Engineering, University of Niš, Serbia \\ ${ }^{2}$ Faculty of Mechanical Engineering, University "Sts Cyril and Methodius" Skopje, \\ Macedonia
}

\begin{abstract}
Daily emissions of greenhouse gasses have a negative impact on the quality of the atmosphere. In almost every sector there is a certain emission of these gasses. This means that every sector, whether it is the energy, industry, transport sector or the household has a part in the degradation of the environment. In this connection, many models have been developed, whose task is to reduce greenhouse gas emissions and carbon dioxide as well to improve the environmental quality. This paper will discuss the carbon footprint model. A carbon footprint is the set of greenhouse gas emissions caused by something. It can be calculated for a product, service, person or even a country, and is used to understand the impact of human activity on the earth's climate. Also, an analysis of carbon footprint using different types of fuel for heating households will be presented.
\end{abstract}

Key words: carbon footprint, pellet, carbon dioxide, renewable energy, emissions

\section{INTRODUCTION}

Environmental protection has become a topic of discussion between the scientific world and in everyday conversations. Global warming and emissions indicate the deterioration of our environment. Summer temperatures across Europe depict the uniform increase until 2050 by about $1^{\circ} \mathrm{C}-2^{\circ} \mathrm{C}$, except in the West where the temperature will rise by about $2^{\circ} \mathrm{C}-3^{\circ} \mathrm{C}$. Large changes in the average monthly temperature of $8^{\circ} \mathrm{C}-9^{\circ} \mathrm{C}$ refer to the countries of the Balkan region, Austria, as well as some parts of the Italian Alps [1].

The main causes of the negative impacts on the environment are the use of nonrenewable energy sources. In all modern countries more and more energy is used and the world has become addicted to the quantity of available energy. There is a constant striving for the study of processes and technologies that use renewable energy. There are protocols governing the use of renewable energy sources and prescribed laws on reducing

Received December 20, 2016 / Accepted March 8, 2018

Corresponding author Milica Jović

Faculty of Mechanical Engineering, University of Niš, , Aleksandra Medvedeva 14, 18000 Niš, Serbia

E-mail: milica.jovic@masfak.ni.ac.rs 
negative impacts on the atmosphere. One of the most popular is the Kyoto protocol [2]. The Kyoto Protocol defines binding targets for reducing emissions by 37 industrialized countries and the European Community during the first implementation period 2008-2012. The Kyoto Protocol was adopted at the third Conference of the Parties to the UN Convention on Climate Change, held in December 1997 in Kyoto, Japan [3]. Kyoto Protocol promotes and encourages research development, increases the use of new and renewable forms of energy and energy sources, encourages technology to control emissions of carbon dioxide and environmentally advanced technologies, imposes measures to limit and reduce emissions of greenhouse gasses (GHG). The most important success of this protocol was the determination of liability limitation and reduction of emissions of six GHG which are: carbon dioxide $\left(\mathrm{CO}_{2}\right)$, methane $\left(\mathrm{CH}_{4}\right)$, nitrous oxide $\left(\mathrm{N}_{2} \mathrm{O}\right)$, hydrofluorocarbons (HFC), perfluorocarbons (PFCs), sulphur hexafluoride (SF6).

The need to include the influence of all these gasses on the environment influenced the development of the concept of a carbon footprint.

\section{METHODOLOGY OF CARBON FOOTPRINT}

Carbon footprint has emerged from the ecological footprint which was developed in 1996 by Wackernagel and Rees [4]. As it can be seen, ecological footprint is a newer field of study of environmental impacts. The ecological footprint is a measure of human demands by the Earth's ecosystems. From this concept, many other concepts, such as carbon footprint, water footprint and land footprint were developed. All these concepts have been studied in environmental protection. In this article, a more detailed analysis of carbon footprint will be presented.

An estimation of approximate values of $\mathrm{CO}_{2}$ emissions, together with a few large greenhouse gasses is called carbon footprint [5]. Carbon footprint has become a widespread concept in estimates of carbon dioxide emissions.

Since the very beginning, the carbon footprint did not have a clear definition of what exactly it constitutes; therefore, many scientists gave their view of the definition of this concept. Some of the definitions of the carbon footprint are as follows:

- Carbon Trust (2007): A technique for identifying and measuring the individual greenhouse gas emissions from each activity within a supply chain process step and the framework for attributing these to each output product [6].

- Wackernagel (2008): CF measures how much land would be required to absorb our emissions of carbon dioxide from fossil fuel (minus what is absorbed by the oceans), [7].

- Larsen \& Hertiwch (2009): The lifecycle GHG emissions caused by the production of the goods and services consumed by a geographically-defined population or activity, independent of whether the GHG emissions occur inside or outside the geographical borders of the population or activity of interest [8].

- Peters (2010): The 'carbon footprint' of a functional unit is the climate impact under a specified metric that considers all relevant emission sources, sinks, and storage in both consumption and production within the specified spatial and temporal system boundary [9]. 
- Pandey et al. (2011): 'the quantity of GHGs expressed in terms of $\mathrm{CO}_{2}$-equivalent, emitted into the atmosphere by an individual, organization, process, product, or event from within a specified boundary', [10].

As it has already been mentioned, carbon footprint can be calculated for different sectors, products, and per person. Carbon footprint expressed through $\mathrm{CO}_{2} \mathrm{e} . \mathrm{CO}_{2^{-}}$ equivalents are calculated by multiplying the various GHG emissions by their 100-year global warming potential.

\section{Calculation Methods}

In order to apply the method to calculate the carbon footprint, it is necessary to define the scope in order to properly define what count and how to avoid repeating carbon footprint in the aggregate [11]. These three scopes are:

- Scope 1 refers to the accounting of direct GHG emissions, which occur from sources that are owned or controlled by the company (e.g. the emissions from combustion in owned or controlled boilers, furnaces, vehicles).

- Scope 2 refers to accounting of indirect GHG emissions from the generation of purchased electricity used by the company.

- Scope 3 refers to other indirect GHG emissions, which are a consequence of the activities of the company, but occur from sources not owned or controlled by it (e.g. extraction and production of purchased materials, transportation of purchased fuels).

The general form of the equation to calculate the carbon footprint is [12]:

Carbon footprint of a given activity $=$ Activity data $($ mass $/$ volume $/ \mathrm{kWh} / \mathrm{km}) \times$ Emission factor $\left(\mathrm{CO}_{2}\right.$ e per unit)

In this paper, the carbon footprint generated by burning different types of fuel has been analyzed. The analysis indicated both the cases of using non-renewable and renewable fuels. The following table shows the emissions of $\mathrm{CO}_{2}$ e per unit for certain types of fuel.

Table 1. Emission factor for different fuels [13]

\begin{tabular}{lc}
\hline Fuel & $\mathrm{CO}_{2}$ e $\mathrm{kg} / \mathrm{kWh}$ \\
Fuel oil & 0,325 \\
Lignite & 0,33 \\
Brown coal & 0,32 \\
Electricity & 0,53 \\
Pellet & 0,29 \\
\hline
\end{tabular}

The lowest emission of carbon dioxide equivalent has a pellet. In the following work, we will show the level of household emission and the amount of savings and reducing GHG emissions when using biofuels or pellets. 


\section{DESCRIPTION OF THE FAMILY HOUSEHOLD}

The family house, which was taken for discussion is located in Skopje, Macedonia. The house area is $120 \mathrm{~m}^{2}$ and it consists of a ground floor and a first floor. The building construction is from reinforced concrete. The basis and the foundation walls are reinforced concrete and over them the base floor is set up. The concrete base is $10 \mathrm{~cm}$ thick. A polyethylene film of $0.002 \mathrm{~cm}$ and concrete screed of $5 \mathrm{~cm}$ is laid on it.

The external walls are made of $20 \mathrm{~cm}$ thick block with thermal insulation of $10 \mathrm{~cm}$. On the inner side, the walls are plastered with mortar $2.5 \mathrm{~cm}$ thick.

The floors in the house are covered with parquet flooring and ceramic tiles, under which a final cladding are set over the screed.

The roof is designed as a conventional roof, and the attic is designed as a ventilated area with two windows. The attics are built with a concrete slab of $10 \mathrm{~cm}$ covered with 10 $\mathrm{cm}$ thermal insulation (glass wool). The windows are with the plastic frame (PVC) and double glass. The building is heated with radiators - district heating.

This chapter presents a mathematical model of heat loss in a building. It is necessary to calculate the total need of heat energy for households to continue to be able to calculate the carbon footprint.

The required amount of heat for heating the household is calculated [14] by the equation (1):

$$
\mathrm{Q}=\mathbf{k} \cdot \mathrm{A} \cdot \Delta \mathrm{T}[\mathrm{W}]
$$

Where:

$$
\begin{aligned}
& \mathrm{k} \text { - heat transfer coefficient }\left[\mathrm{W} / \mathrm{m}^{2} \mathrm{~K}\right] \\
& \mathrm{A} \text { - surface area }\left[\mathrm{m}^{2}\right] \\
& \Delta \mathrm{T}^{-} \text {temperature difference }[\mathrm{K}]
\end{aligned}
$$

Heat transfer coefficient is determined based on the following equation:

$$
k=\frac{1}{\frac{1}{\alpha_{v}}+\Sigma \frac{\delta i}{\lambda i}+\frac{1}{\alpha_{n}}}\left[\frac{\mathrm{W}}{\mathrm{m}^{2} \mathrm{~K}}\right]
$$

Where

$$
\begin{array}{cl}
\alpha_{v,} \alpha_{n} & - \text { the convective coefficient on the inner and outer layer }\left[\mathrm{W} / \mathrm{m}^{2} \mathrm{~K}\right] \\
\delta & - \text { the thickness of the layer }[\mathrm{m}] \\
\lambda & - \text { the coefficient of thermal conductivity }\left[\mathrm{W} / \mathrm{m}^{2} \mathrm{~K}\right]
\end{array}
$$

Transmission heat losses are losses of heat through the surrounding surfaces (walls, ceilings, floors, doors and windows), when the temperature of air in the room is higher than the temperature of the air on the other side of the fence area. Transmission heat losses are determined by the equation for the heat transfer in steady state:

$$
\mathrm{Q}_{0}=\sum_{\mathrm{i}=1}^{\mathbf{n}} \mathbf{K}_{\mathrm{i}} \times \mathbf{A} \times\left(\mathrm{t}_{\mathrm{v}}-\mathbf{t}_{\mathbf{n}}\right) \quad[\mathrm{W}]
$$


This heat loss $\mathrm{Q}_{0}$ are increased by additions for a break in the firing and orientation of the building

$$
Q_{t}=Q_{0}\left(1+z_{1}+z_{2}\right)[W]
$$

The coefficient $z_{1}$ and $z_{2}$ are the supplements that are related to a break in the firing and on the side of the world where the object is located. Their value is experimentally determined and taken from a table.

\section{THE CALCUlation Results}

The calculation for the annual demand of thermal energy for this household according to the mathematical models presented in the previous section is $14000 \mathrm{~W}$. The required amount of heat for heating the building depends on many factors such as: the size of the object, the purpose of the rooms, the climate region where the building is located and the construction of the building. All factors that influence the amount of heat required for heating the building are taken into consideration. For this analysis, a $15 \mathrm{~kW}$ boiler required for heating was chosen.

The Table 2 shows the value of the carbon footprint that is calculated for different types of fuels whose emissions are given previously in this paper.

\section{Carbon footprint}

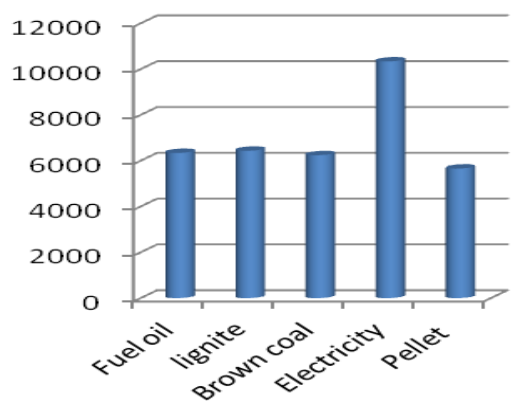

Table 2 The carbon footprint for different fuel

\begin{tabular}{ll}
\hline Fuel & $\begin{array}{l}\text { Carbon footprint } \\
{\left[\mathrm{kgCO}_{2} \mathrm{e} / \text { year }\right]}\end{array}$ \\
\hline Fuel oil & 6337,5 \\
lignite & 6435 \\
Brown coal & 6240 \\
Electricity & 10335 \\
Pellet & 5655 \\
\hline
\end{tabular}

Fig. 1 The carbon footprint for different fuel

From Fig. 1 and in the Table 2, it can be concluded that the minimum value of the carbon footprint is achieved using a pellet. By comparing pellets with electricity, it can be seen that in case of this household this difference is almost double. This indicates the need to reduce the use of electric energy for heating purposes and use other fuels. Fuel oil, lignite and brown coal have approximately the same value of the carbon footprint because emission factor $\mathrm{CO}_{2} \mathrm{e}$ has approximately the same value. From this analysis it can be concluded that if the households aims to reduce greenhouse gas emissions renewable energy sources should be used (for example pellets).

Globally, the interest in the use of new and renewable energy is growing, especially biomass fuel due to its carbon neutral properties. Solid biofuel pellets, is gaining global interest due to its homogenous quality regarding particle density, moisture contents, and uniform shape and size. The wood pellets are produced from sawdust and waste wood 
after crushing, drying, and compression [15]. Wood pellets are suitable for transport, storage, and use in a heating system. There are key environmental benefits associated with wood pellet boilers. This is because if the biomass fuel is fully combusted, the amount of carbon dioxide produced is equal to the amount which was taken from the atmosphere during the growing stage. Localized production of wood pellets has the added advantage of supporting local economies by providing new employment opportunities.

\section{DESCRIPTION OF PELLET BOILER}

In this part of the paper, pellet boiler with its own characteristics will be presented. This boiler meets the needs of the family home described earlier in this paper. A pellet boiler from the manufacturer EcoSpar, Ohrid, Macedonia is analyzed [16]. The boiler starts to burn pellets with the push of a single button. This model has the power of $15 \mathrm{~kW}$ that are ideal for warming up spaces between 120 and $150 \mathrm{~m}^{2}$. It's designed to be positioned in the living room and has a big glass window that simplifies the spreading of the warmth from the boiler and shows the direct source of the comfort in the house.

Pellet boiler is designed by the EN 14785, EN 303-5, ISO: 9001 standards and the CE Declaration. A burner is made of a special metal sheet. The inner part of the burner is double coated metal sheet, thus provides the higher thermal power of the boiler. The burner has a door with ceramic glass that is durable at temperatures up to $700^{\circ}$. The doors are hermetically sealed. The considered pellet boiler is shown in Figure 2.

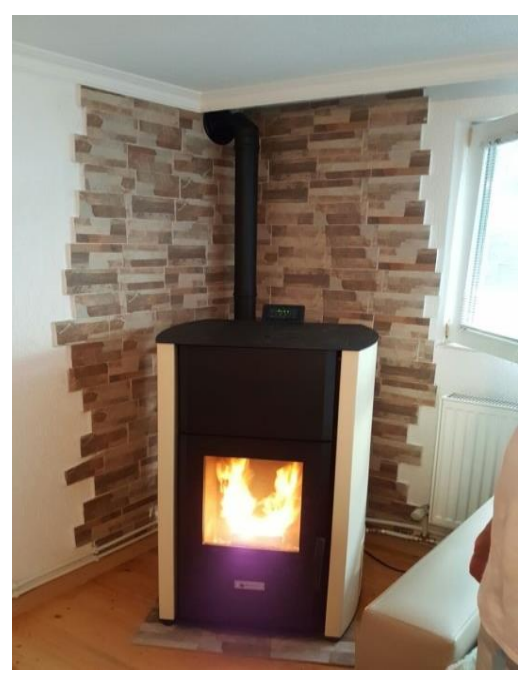

Fig. 2 Considered pellet boiler

The characteristics of the control unit of the boiler are: simple design, easy control, fast installation.

Safety devices of boiler have the following characteristics: protection from overheating, monitoring the temperature of exhaust gasses, monitoring boiler - water temperature, the inability for penetration of sparks into the tank with pellets. 


\section{CONCLUSION}

There is a daily tendency to reduce $\mathrm{CO}_{2}$ emissions. The concept of carbon footprint is a very useful methodology for defining $\mathrm{CO}_{2} \mathrm{e}$ emissions. Carbon footprint has appeared as a strong and popular indicator of greenhouse gasses with special emphasis on carbon dioxide. This methodology can be applied in all sectors. In this work, it is used to define the impact of greenhouse gas emissions from households. With this analysis, which included the use of heating oil, lignite, brown coal, electricity and wood pellets for heating a family home, it was concluded that the use of pellets had the lowest impact on the environment. The reason for this is that the pellets are carbon dioxide neutral fuels, i.e. the amount of carbon dioxide produced is equal to the amount which was taken from the atmosphere during the growing stage. In the future, individual households should strive to use this type of fuel for heating and on that way each individual household will make great importance to environmental protection.

Also, an example of a pellet boiler is presented in this paper. There are many manufacturers of pellet boilers but, in this paper, the authors decided to show the boiler manufacturers from the domestic market. Handling these boilers is very simple and provides a number of benefits to people. However, it is necessary to inform citizens about all the benefits that come with the application of these boilers. In the near future, there should be more frequent public discussions in the field of renewable energy for heating purposes, which would awaken the awareness of citizens to make a profound contribution to the preservation of the environment.

\section{REFERENCES}

1. Lakovic and others, "Coal-fired power plants energy efficiency and climate change-current state and future trend”, Facta Universitatis, Series: Working and Living Environmental Protection, Vol. 12, No 2, pp 217-227, 2015

2. United Nations, United Nations Framework Convention on Climate Change, Kyoto Protocol, 1997

3. http://www.kyotoprotocol.com/ [accessed 19.12.2016]

4. Wackernagel M, Rees WE., "Our ecological footprint: Reducing human impact on Earth", New Society Publishers, Gabriola Island, BC, 1996

5. Wiedmann T., Minx J., "A definition of carbon footprint", ISAUK Research report 07-01, Durham, 2007

6. Carbon Trust., "Carbon Footprint Measurement Methodology, Version 1", The Carbon Trust, London, UK, 2007

7. M. Wackernagel, "Measuring Ecological Footprints", in OECD, ed, Measuring Sustainable Production. 4 edn. Paris, pp. 49-59, 2008.

8. Larsen HN, Hertwich EG. "The case for consumption-based accounting of greenhouse gas emission to promote local climate action”, Environmental science and policy, pp. 791-798, 2009.

9. Peters GP, "Carbon footprints and embodied carbon at multiple scales", Current Opinion in Environmental Sustainability 2, pp. 245-250, 2010

10. Pandey D, Agrawal M, Pandey JS., "Carbon footprints: current methods of estimation", Environ Monit Assess, pp.135-160, 2011

11. Matthews, H. S., Hendrickson, C. T. and Weber, C. L "The importance of carbon footprint estimation boundaries", Environmental Science \& Technology, Vol. 42, No. 16, pp. 5839-42, 2008

12. Chrysi Laspidou and others, "Carbon Footprint Calculation Of Desalination Units In Greece", Fresenius Environmental Bulletin, Volume 21, No. 8b, January 2012

13. Pravilnik o energetskoj efikasnosti zgrada, "Sl. glasnik RS", br. 61/2011

14. Laković, S., Thermal plants, (In Serbian), Faculty of Mechanical Engineering, Nis, Serbia, 1975

15. Seung Hee Euh and others, "A study on the effect of tar fouled on thermal efficiency of a wood pellet boiler: A performance analysis and simulation using Computation Fluid Dynamics", Energy, 103, pp. 305-312, 2016

16. http://www.ecospar.com.mk/ [accessed 19.12.2016] 


\section{KARBONSKI OTISAK KOD DRVENIH PELETA}

Emisije gasova sa efektom staklene bašte na dnevnom nivou imaju izuzetno negativan uticaj na kvalitet atmosferskog vazduha. Emisija ovih gasova je prisutna u skoro svakom sektoru. Na taj način, sve industrijske grane, uključujući sektor energetike, transporta, pa čak i domaćinstva, imaju ulogu u narušavanju životne sredine. S tim u vezi, razvijeni su različitimodeli čiji je cilj smanjenje emisije gasova sa efektkom staklene bašte i smanjenje ugljen-dioksida, kao i poboljšanje kvaliteta životne sredine. Tema ovog rada je model karbonskog otiska. Karbonski otisak predstavlja ukupnu količinu proizvedenih emisija gasova sa efektom staklene bašte. Može se izračunati za proizvod, uslugu, osobu, čak i za zemlju, $i$ koristi se za razumevanje uticaja čovekovih aktivnosti na klimu. Takođe, u radu će biti predstavljena analiza karbonskog otiska nakon upotrebe različitih vrsta goriva za grejanje u domaćinstvima.

Ključne reči: karbonski otisak, peleti, ugljen-dioksid, obnovljivi izvori energije, emisije 